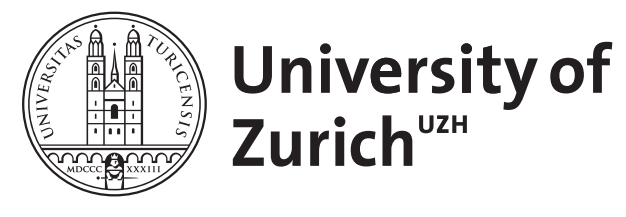

\title{
Chromosomal map of human brain malformations
}

\author{
Tyshchenko, N ; Lurie, I ; Schinzel, A
}

\begin{abstract}
The etiology of most central nervous system (CNS) malformations remains unknown. We have utilized the fact that autosomal chromosome aberrations are commonly associated with CNS malformations to identify new causative gene loci. The human cytogenetic database, a computerized catalog of the clinical phenotypes associated with cytogenetically detectable human chromosome aberrations, was used to identify patients with 14 selected brain malformations including 541 with deletions, and 290 carrying duplications. These cases were used to develop an autosomal deletion and duplication map consisting of 67 different deleted malformation associated bands (MABs) in 55 regions and 88 different duplicated MABs in 36 regions; 31 of the deleted and 8 duplicated MABs were highly significantly associated $(\mathrm{P}<0.001)$. All holoprosencephaly MABs found in the database contained a known HPE gene providing some level of validation for the approach. Significantly associated MABs are discussed for each malformation together with the published data about known disease-causing genes and reported malformation-associated loci, as well as the limitations of the proposed approach.
\end{abstract}

DOI: https://doi.org/10.1007/s00439-008-0528-2

Posted at the Zurich Open Repository and Archive, University of Zurich ZORA URL: https://doi.org/10.5167/uzh-6423

Journal Article

Published Version

Originally published at:

Tyshchenko, N; Lurie, I; Schinzel, A (2008). Chromosomal map of human brain malformations. Human genetics, 124(1):73-80.

DOI: https://doi.org/10.1007/s00439-008-0528-2 


\title{
Chromosomal map of human brain malformations
}

\author{
Nataliya Tyshchenko $\cdot$ Iosif Lurie $\cdot$ Albert Schinzel
}

Received: 18 March 2008 / Accepted: 12 June 2008 / Published online: 18 June 2008

(c) Springer-Verlag 2008

\begin{abstract}
The etiology of most central nervous system (CNS) malformations remains unknown. We have utilized the fact that autosomal chromosome aberrations are commonly associated with CNS malformations to identify new causative gene loci. The human cytogenetic database, a computerized catalog of the clinical phenotypes associated with cytogenetically detectable human chromosome aberrations, was used to identify patients with 14 selected brain malformations including 541 with deletions, and 290 carrying duplications. These cases were used to develop an autosomal deletion and duplication map consisting of 67 different deleted malformation associated bands (MABs) in 55 regions and 88 different duplicated MABs in 36 regions; 31 of the deleted and 8 duplicated MABs were highly significantly associated $(P<0.001)$. All holoprosencephaly MABs found in the database contained a known HPE gene providing some level of validation for the approach. Significantly associated MABs are discussed for each malformation together with the published data about known diseasecausing genes and reported malformation-associated loci, as well as the limitations of the proposed approach.
\end{abstract}

N. Tyshchenko $(\bowtie) \cdot$ A. Schinzel

Institute of Medical Genetics,

University of Zurich, 8603 Schwerzenbach, Switzerland

e-mail: nataliya.tyshchenko@tu-dresden.de

I. Lurie

Maryland Physicians Associates, Baltimore, MD, USA

Present Address:

N. Tyshchenko

Institute of Clinical Genetics,

Technical University Dresden, Dresden, Germany

\section{Introduction}

Congenital malformations of the CNS are common birth defects with a birth prevalence of about $1 \%$ (Arvanitis 1999). Although mutations have been identified in more than 37 different genes in CNS malformations (Sarnat 2005) the etiology of the majority of cases remains unknown. For example, in holoprosencephaly (HPE) every identified mutation in known HPE-associated genes occurs in less than $4 \%$ of cases, and almost all of those are sporadic. (Cohen 2004). The Human malformation map has been updated recently (Carey and Viskochil 2007), however, only some of the brain malformations discussed here are included (HPE, lissencephaly and Dandy-Walker malformation).

Chromosome aberrations provide us with an important clue for the location of genes involved in congenital defects, since clinical and molecular cytogenetic data can be used to identify regions highly associated with birth defect of interest. A first analysis of the association of chromosomal imbalance with congenital malformations based on clinical and cytogenetic data has been performed in 1998 (Brewer et al. 1998, 1999). Many and especially frequent CNS malformations are common in autosomal chromosome aberrations (Schinzel 2001). In this work, we focus on the delineation of gene loci significantly associated with specific brain malformations using an unpublished updated version of the database which includes about 3000 additional entries. As the latter stem from more recent publications (after 1994), the breakpoint determination can be considered more precise and reliable as compared to the cases used in the aforementioned study. 


\section{Materials and methods}

Case selection

The human cytogenetic database (HCD) is an expertly curated computerized catalog of postnatally ascertained, cytogenetically detectable human chromosome aberrations. The first edition of HCD was published in 1994 (Human Cytogenetics Database 1994). A recent version of HCD contains more than 9,200 published cases with over 2,800 different aberrations (unpublished data). A search of HCD was performed for the brain malformations shown in Table 1 . The selection was determined by the search mode of HCD (identical to London Dysmorphology Database). We excluded brain abnormalities not common in chromosomal aberrations (such as brain tumors, vascular abnormalities, hamartomas, neuronal migration abnormality), abnormalities which are unspecific and likely to have environmental causes (such as cerebral atrophy and intracranial calcification), and generalized terms (such as pons/medulla/ basal ganglia/abnormal).

Cytogenetic and clinical data on individuals with nonmosaic simple deletions/duplications (those involving a single contiguous region of autosomal DNA) were extracted. Complex rearrangements were excluded to avoid any modifying effects (Lurie 1993). The International System for Human Cytogenetic Nomenclature (Shaffer and Tommerup 2005), 400-band nomenclature, was used to describe the deletions/duplications. A 400-band level was chosen taking into account that HCD contained cases since 1962, when high resolution banding technique did not exist. Deletions/duplications involving subbands were scored as

Table 1

1. Holoprosencephaly (HPE)
Cyclopia
Premaxillary agenesis
2. Dandy-Walker malformation (DWM)
3. Agenesis of corpus callosum (ACC)
4. Schizencephaly
5. Cerebellar abnormalities
6. Lissencephaly
7. Pachygyria
8. Anencephaly
9. Neural tube defects (excluding anencephaly) (NTD)
Anterior encephalocele
Posterior encephalocele
Meningocele/spina bifida
Spina bifida occulta
10. Arnold-Chiari malformation
11. Aqueduct stenosis

including the whole band, breakpoints bands were scored as deleted/duplicated.

Statistical analysis

For the 14 malformation entities studied, the observed number of deletions/duplications of a particular band was compared with the expected number calculated from the band distribution of all band deletions/duplications (Brewer et al. 1998, 1999). The Fisher exact test was used to evaluate an association between deletion/duplication in a particular band and presence of a malformation (SPSS 13, Inc., Chicago). Chromosomal bands found to be significantly associated $(P<0.05)$ with a given malformation, so called malformation-associated bands (MABs) (Brewer et al. 1998), were subdivided into three groups according to the $P$ value: (1) $P<0.05$, (2) $P<0.01, P>0.001$ and (3) $P<0.001$.

Validation of bands and regions

A systematic analysis of all published array-CGH studies was performed to define cases with the malformations of interest.

The candidate gene approach was used to identify genes hemizygosity of which can result in brain malformation. The list of genes localized on the bands found to be significantly associated with brain defects that were not previously reported were downloaded from Entrez Genome View (http://www.ncbi.nlm.nih.gov/mapview/map_search. cgi; access July 2006). Candidates were selected according to known biological function, pattern of tissue expression, similar malformations in knockout organisms.

\section{Results}

Identifying MABs

Three thousand one hundred and eighty nine cases with simple autosomal deletions and 2,178 cases with simple autosomal duplications were identified in the HCD. Five hundred and forty one patients with deletions and 290 with duplications were cataloged as having one of the 14 brain malformations chosen for the study. Schizencephaly $(0$ cases), pachygyria (4 cases) and aqueductus stenosis (1 case) had to be excluded because the number of cases associated with simple deletions and duplications was too small for useful analysis. The group of cerebellar anomalies was also excluded due to poor clinical definition (doubtful results of the investigations, lack of MRI, etc.).

Significant associations were found for 67 different deleted malformation associated bands (MABs) in 55 
regions and 88 different duplicated MABs in 36 regions; 31 of the deleted and 8 duplicated MABs were highly significantly associated $(P<0.001)$ (Tables 2,3$)$.

The distribution of aberrations throughout the autosomes was not random. Deletions of chromosome 12, 16, 19 and 21 were not associated with any of the brain malformations studied.
Further delineation of MABs

In order to narrow down candidate chromosome regions, all published array-CGH and larger subtelomere FISH studies were analyzed to define cases with the malformations of interest. From 2001 to 2006 eight studies (a total of 575 patients with mental retardation) have been published

Table 2 Deleted regions significantly associated with brain malformations

\begin{tabular}{|c|c|c|c|c|}
\hline Malformation & $\begin{array}{l}\text { No. of } \\
\text { cases }\end{array}$ & All MABs $(P<0.05)$ & $\begin{array}{l}\text { MABs }(P<0.01 \\
P>0.001)\end{array}$ & MABs $(P<0.001)$ \\
\hline Holoprosencephaly & 111 & $\begin{array}{l}2 \mathrm{p} 23,2 \mathrm{p} 22,2 \mathrm{p} 21,7 \mathrm{q} 32-\mathrm{q} 36 \\
13 \mathrm{q} 22-13 \mathrm{q} 34,18 \mathrm{p} 11.3-11.1\end{array}$ & $13 q 22$ & $\begin{array}{l}2 \mathrm{p} 22,2 \mathrm{p} 21,7 \mathrm{q} 32-\mathrm{q} 36 \\
13 \mathrm{q} 31-\mathrm{q} 34,18 \mathrm{p} 11.3-11.1\end{array}$ \\
\hline Cyclopia & 5 & 2p23-p21, 18p11.3-p11.1 & & $2 \mathrm{p} 22-\mathrm{p} 21$ \\
\hline Premaxillary agenesis & 6 & 18p11.3-p11.1 & & 18p11.3-p11.1 \\
\hline Dandy-Walker malformation & 18 & $3 \mathrm{q} 25-\mathrm{q} 26.3,6 \mathrm{p} 25-\mathrm{p} 23$ & $3 q 25$ & $3 q 26.1-q 26.3,6 \mathrm{p} 25,6 \mathrm{p} 24$ \\
\hline Agenesis of corpus callosum & 145 & $\begin{array}{l}1 \mathrm{q} 42-\mathrm{q} 44,2 \mathrm{p} 22,2 \mathrm{q} 13-\mathrm{q} 14.3,2 \mathrm{q} 21 \\
3 \mathrm{q} 13.1-\mathrm{q} 21,4 \mathrm{q} 21,6 \mathrm{q} 25-\mathrm{q} 26 \\
(6 \mathrm{q} 27,13 \mathrm{q} 32,14 \mathrm{q} 11.2-\mathrm{q} 21 \\
15 \mathrm{q} 15,17 \mathrm{p} 13\end{array}$ & $\begin{array}{l}2 \mathrm{q} 14.2-\mathrm{q} 21,3 \mathrm{q} 13.3 \\
\quad 6 \mathrm{q} 25,6 \mathrm{q} 27,14 \mathrm{q} 21\end{array}$ & $1 \mathrm{q} 42-\mathrm{q} 44,14 \mathrm{q} 11.2-\mathrm{q} 13,17 \mathrm{p} 13$ \\
\hline Anencephaly & 4 & $13 q 31-q 34$ & $13 q 32-q 34$ & \\
\hline $\begin{array}{l}\text { Neural tube defects } \\
\text { (without anencephaly) }\end{array}$ & 84 & $1 q 42-q 44,2 q 36,13 q 22-q 34$ & $1 q 43,2 q 36$ & $13 q 22-q 32,13 q 33-q 34$ \\
\hline Anterior encephalocele & 4 & $1 \mathrm{q} 43-\mathrm{q} 44,11 \mathrm{p} 12-\mathrm{p} 11.2$ & $1 q 43-q 44$ & \\
\hline Posterior encephalocele & 15 & $1 q 41-q 44,2 q 24-q 31,13 q 22-q 34$ & $1 \mathrm{q} 42-\mathrm{q} 44,2 \mathrm{q} 24,13 \mathrm{q} 22$ & $13 q 31-q 34$ \\
\hline Meningocele/spina bifida & 16 & $1 \mathrm{q} 43-\mathrm{q} 44,2 \mathrm{q} 35-\mathrm{q} 36,22 \mathrm{q} 11.2$ & $1 q 43,2 q 36,2 q 11.2$ & $2 q 35-q 36$ \\
\hline Spina bifida occulta & 51 & 4p15.2-p15.1, 9q22 13q31-q34, 20p13 & $13 q 33$ & \\
\hline Lissencephaly & 26 & $14 \mathrm{q} 11.2-\mathrm{q} 13,17 \mathrm{p} 13,22 \mathrm{q} 12$ & & $14 q 11.2-q 13,17 p 13$ \\
\hline Arnold-Chiari malformation & 7 & $1 q 23-q 24,1 q 31,2 q 35-q 36,5 q 23,6 q 21$ & & $2 q 35-q 36$ \\
\hline
\end{tabular}

Table 3 Duplicated regions significantly associated with brain malformations

\begin{tabular}{|c|c|c|c|c|}
\hline Malformation & $\begin{array}{l}\text { No. of } \\
\text { cases }\end{array}$ & All MABs $(P<0.05)$ & $\begin{array}{l}\text { MABs }(P<0.01 \\
P>0.001)\end{array}$ & $\begin{array}{l}\text { MABs } \\
(P<0.001)\end{array}$ \\
\hline Holoprosencephaly & 34 & $\begin{array}{c}\text { 3p26-p21, 3q11.1, 3q11,2, 3q23, 3q29, } \\
\text { 5q32-q34, 6p25-p21.1, 13q14-q34 }\end{array}$ & $3 \mathrm{p} 24-\mathrm{p} 22,6 \mathrm{p} 21.2-\mathrm{p} 21.1$ & $3 \mathrm{p} 26,3 \mathrm{p} 25$ \\
\hline Cyclopia & 1 & $3 \mathrm{p} 26-\mathrm{p} 22$ & & \\
\hline Premaxillary agenesis & 4 & $5 q 32-q 34$ & & \\
\hline Dandy-Walker malform. & 15 & $12 \mathrm{q} 24.3,17 \mathrm{q} 21,17 \mathrm{q} 22$ & & \\
\hline Agenesis of corpus callosum & 73 & $1 \mathrm{p} 32,6 \mathrm{p} 21.3-\mathrm{p} 21.1,8 \mathrm{p} 23-\mathrm{p} 11.1$ & $8 \mathrm{p} 23$ & $8 \mathrm{p} 22,8 \mathrm{p} 21$ \\
\hline Anencephaly & 9 & $2 \mathrm{p} 25-\mathrm{p} 22$ & & $2 \mathrm{p} 25-\mathrm{p} 22$ \\
\hline $\begin{array}{l}\text { Neural tube defects } \\
\text { (without anencephaly) }\end{array}$ & 49 & $1 \mathrm{q} 43-\mathrm{q} 44,2 \mathrm{p} 16-\mathrm{p} 13,20 \mathrm{p} 13-\mathrm{p} 11.1$ & & \\
\hline Anterior encephalocele & 3 & $1 q 11-q 24,7 p 12-q 11.1$ & & \\
\hline Posterior encephalocele & 1 & $8 \mathrm{q} 22-\mathrm{q} 24.3$ & & \\
\hline $\begin{array}{l}\text { Meningocele/ } \\
\text { spina bifida }\end{array}$ & 9 & $2 \mathrm{p} 25 \mathrm{p} 13$ & $2 \mathrm{p} 16-\mathrm{p} 13$ & \\
\hline Spina bifida occulta & 37 & 4p13-p11, 20p13-p11.1 & & \\
\hline Lissencephaly & 0 & & & \\
\hline Arnold-Chiari malform. & 1 & $5 \mathrm{p} 15.3-\mathrm{p} 11$ & & \\
\hline Aqueduct stenosis & 5 & $17 \mathrm{p} 13$ & & \\
\hline
\end{tabular}


where array CGH screenings of different series of patient were performed (de Vries et al. 2005; Joly et al. 2001; Menten et al. 2006; Poss et al. 2006; Rosenberg et al. 2006; Schoumans et al. 2005; Shaw-Smith et al. 2004; Tyson et al. 2005). Surprisingly, only a few patients with cryptic chromosomal aberrations were described with brain malformations, most often Agenesis of corpus callosum (ACC) and Dandy-Walker malfromation. All but one rearrangement differed from the MABs determined in our study. Rosenberg et al. (2006) reported an aCGH investigation of 81 patients with mild to severe mental retardation and one of the patients with a de novo $\operatorname{del}(13)(q 32.3)$ was found to have ACC, which corresponds to ACC and HPE associated MABs determined in our study.
Identification of candidate genes

Two interesting malformation-associated loci were selected for candidate gene identification. $3 q 13.3$ is significantly associated with ACC, and 1q42-q44 is associated with both ACC and NTD. 55 genes map within $3 q 13.3$ and 294 within 1q42-q44 (Entrez Genome View, access July 2006). Pseudogenes and genes with unknown function not expressed in neural tissue were excluded from further analysis. Genes of unknown function but expressed in neural tissue during embryonic development have been considered as genes with possible involvement, along with genes taking part in different pathways known to be important during CNS embryogenesis (Tables 4, 5).
Table 4 Possible candidate genes for agenesis of corpus callosum and neural tube defects

\begin{tabular}{ll}
\hline Possible candidate genes & Reference \\
\hline 1q42-q44 & \\
$\begin{array}{l}\text { WNT3A, wingless-type MMTV integration site family, } \\
\text { member 3A }\end{array}$ & Gunhaga et al. (2003) \\
RHOU, ras homolog gene family, member U & Kirikoshi and Katoh (2002) \\
DISC1, disrupted in schizophrenia 1 & Morris et al. (2003) \\
& Ozeki et al. (2003) \\
$\begin{array}{l}\text { GNG4, guanine nucleotide binding protein (G protein), } \\
\text { gamma } 4\end{array}$ & Ray et al. (1995) \\
FMN2, formin 2 & \\
GREM2, gremlin 2, cysteine knot superfamily, & Leader and Leder (2000) \\
homolog (Xenopus laevis) & Avsian-Kretchmer and Hsueh (2004) \\
OPN3, opsin 3 (encephalopsin, panopsin) & \\
ZNF238, zinc finger protein 238 & Halford et al. (2001) \\
$3 \mathrm{q} 13.3$ & Becker et al. (1997) \\
GAP43, growth associated protein 43 & \\
GPR156, G protein-coupled receptor 156 & Strittmatter et al. (1995) \\
RABL3 RAB, member of RAS oncogene family-like 3 & Calver et al. (2003) \\
FBXO40, F-box protein 40 & Strausberg et al. (2002) \\
LSAMP, limbic system-associated membrane protein & Nagase et al. (1999) \\
\hline
\end{tabular}

Table 5 Strong candidate genes for agenesis of corpus callosum and neural tube defects

\begin{tabular}{|c|c|c|}
\hline $\begin{array}{l}\text { Chromosome } \\
\text { band }\end{array}$ & Gene & Description \\
\hline $3 q 13.3$ & $C D G A P$, Cdc 42 GTPase-activating protein & $\begin{array}{l}\text { GTPase activator; expressed in the corpus callosum } \\
\text { and fetal brain (Nagase et al. 1999) }\end{array}$ \\
\hline $3 q 13.3$ & IGSF11, immunoglobulin superfamily, member 11 & $\begin{array}{l}\text { Cell adhesion molecule; expressed in commissure fibers } \\
\text { of the corpus callosum (Harada et al. 2005; Suzu et al. 2002) }\end{array}$ \\
\hline $1 \mathrm{q} 42 *$ & $D I S P A$, dispatched homolog 1 & $\begin{array}{l}\text { Integral membrane protein; plays an essential role in } \mathrm{Hh} \\
\text { patterning activities in Drosophila; Cephalic defects } \\
\text { in knock-out mice are reminiscent of holoprosencephaly, } \\
\text { embryos display also neural tube patterning defects (Ma et al. 2002) }\end{array}$ \\
\hline
\end{tabular}

* 1q42-q44 found to be significantly associated $(P<0.01)$ both with ACC and neural tube defects 


\section{Discussion}

Human autosomal aberrations are characterized by a combination of non-specific phenotypic effects, such as intrauterine and postnatal growth retardation, craniofacial dysmorphisms, and impaired mental development (Schinzel 2001). Malformations are also common but it is rare for specific malformations to be invariably associated with a specific chromosome aberration. However, clinically recognizable chromosomal syndromes (Wolf-Hirschhorn syndrome, Cri du Chat syndrome, Down syndrome, Cat Eye syndrome etc.) suggest that hemizygosity or duplication of some of the affected genes have a direct negative effect on a particular developmental process. Consequently the recognition of a significant association between a congenital malformation and deletion or duplication of a specific locus may help in the identification of causative genes. The first systematic analysis of clinical and cytogenetic information associated with a large number of autosomal deletions and duplications was made by Brewer et al. $(1998,1999)$ to construct a chromosomal map showing association of congenital malformations and chromosomal regions. In the last 10 years HCD has doubled the number of cases available for statistical analysis and here we identify new MABs for an important group of malformations. It was gratifying to note that all the holoprosencephaly (HPE) deleted MABs identified in this study contained a known causative gene for HPE (Table 2; 2p21-SIX2 gene, 7q36-SHH gene, $13 \mathrm{q} 32-$ ZIC2 gene, and 18p11.3-TGIF gene). HPE is a malformation representing a developmental field defect of impaired midline cleavage of the embryonic forebrain (Cohen 2001) Unsurprisingly, cyclopia and premaxillary agenesis were associated with HPE deletion MABs, (2)(p23-p21) and (18)(p11.1-p11.3), and are assumed to be caused by hemizygosity of the SIX2 (2p21) and TGIF (18p11.3) genes.

Intragenic mutations mimicking haploinsufficiency are common in human genetics. Duplication is assumed to result in overexpression of the genes within a duplicated region. This is not an effect commonly mimicked by intragenic mutation and it is thus more difficult to assign pathogenesis to individual genes without animal model clues. Overexpression of PAX6 causes eye malformations in transgenic mice (Schedl et al. 1996), and eye abnormalities were also reported in patients carrying a duplication including the PAX6 locus on 11p13 (Aalfs et al. 1997) Several HPE duplication MABs were found (Table 3). Six patients from HCD were reported to have dup(3p) including MABs 3p25-p26 $(P<0.001)$. However they all were associated with terminal monosomies. HPE has not been mapped to 3 p25-p26 previously and was only discussed as an occasional finding in patients with dup3(pter-p21) (Schinzel 2001). In our study all but one duplications found to be significantly associated with HPE represent chromosomal rearrangements resulting from familial translocations. All of these are associated with terminal deletions. The loss of the terminal regions in these cases was previously estimated to be insignificant; therefore the cases were registered as isolated duplications. However, increasing knowledge of the structure of subtelomeric and telomeric regions makes it necessary to analyze the possible impact of combined monosomies. Nevertheless, 3p25-p26 could be a new locus for HPE genes. It was not surprising to identify duplicated MABs on chromosome 13 as this is a characteristic malformation found to be associated with trisomy 13. However, the aberrations in four of five cases with duplications including MABs 13q14-q34 are not pure aberrations (associated with terminal deletions as explained above). Although it is difficult to conclude that either HPE is caused by dup(13q) or that the modifying effects of combined rearrangements play a crucial role, we consider that overexpression of genes located on chromosome 13 may cause HPE.

Dandy Walker malformation (DWM) is characterized by hypoplasia and upward rotation of the cerebellar vermis accompanied by a retrocerebellar cyst which is in communication with the fourth ventricle (Patel and Barkovich 2002). The four highly significant MABs 3q26.1, 3q26.2 and $3 \mathrm{q} 26.3(P<0.001)$ and $3 \mathrm{q} 25(P<0.01, P>0.001)$ (clinical descriptions (Sudha et al. 2001; Willner et al. 1990)) are likely to represent a single locus; indeed, an association of $3 \mathrm{q}$ deletions (3q24.3-q25.33) and DWM has been previously shown. ZIC1 and ZIC4 have been suggested as possible causative genes (Grinberg et al. 2004). A second highly significant region $(P<0.001)$ associated with DWM found in our study is 6p25-p24 which has also been reported (Kelly et al. 1989; Klein et al. 2005; Lin et al. 2005; Mirza et al. 2004), however, no causative gene or genes in that region has/have been identified to date.

Neural tube defects are a group of malformations representing the non-closure of the neural tube resulting in an open or close defect of the cranium or the spine (Panteliadis and Pantzaris 1999). We showed a strong association with anencephaly for $13 \mathrm{q} 22-\mathrm{q} 34(P<0.0001)$. Brown et al. (1993) defined a critical region in 13q32; however, Luo et al. (2000) questioned this finding and suggested deletion in 13q33-q34 as sufficient to cause an NTD. ZIC2 and ZIC5 are considered strong candidate genes for neural tube defects. However, no mutations have yet been described for these genes in humans (Grinberg and Millen 2005). 1q42$\mathrm{q} 44$ was identified as a highly significant region $(P<0.001)$ for NTD as would be predicted from the known clinical syndrome associated with this deletion. Both deletions and duplications of (20)(p13-p11.1) show significant association with spina bifida occulta. OVOL2 (ovo like 2) maps to this region. Murine embryos lacking Ovol2 expression 
show failure of cranial neural tube closure, this might be an evidence for a relationship between spina bifida occulta and open neural tube defects at least in a proportion of cases.

Deletions of $17 \mathrm{p} 13$ encompassing LISI, and loss-offunction mutations in LIS1 both cause lissencephaly (Ledbetter et al. 1992; Lo Nigro et al. 1997). Thus, it has not been a surprise to identify $17 \mathrm{p} 13$ as MAB with the strongest association with lissencephaly $\left(P<2 \times 10^{-50}\right)$.

Agenesis of corpus callosum (ACC) is one of the most frequent human CNS malformations (Bedeschi et al. 2006). The association of ACC with chromosome aberrations has been discussed elsewhere. Schinzel (2001) considered ACC among selected malformations which are particularly common in autosomal chromosome aberrations. The role of $\operatorname{del}(1)(\mathrm{q} 44), \quad \operatorname{del}(2 \mathrm{q}), \quad \operatorname{del}(6)(\mathrm{q} 25), \quad \operatorname{del}(15)(\mathrm{q} 15) \quad$ and $\operatorname{dup}(8)(\mathrm{p} 23-\mathrm{p} 21)$ in the origin of ACC is well-known (Bedeschi et al. 2006; Dobyns 1996; Pirola et al. 1998). One of the best documented chromosomal rearrangements associated with ACC is del(4)(p16), or Wolf-Hirschhorn syndrome. There were 16 cases of isolated del(4)(p16), but taking into account the extreme phenotypic variability of the syndrome (ACC was reported only in $6 \%$ of all registered cases), no statistically significant association could be shown. The low frequency of ACC is partly due to the fact that MRI of the brain is often not performed in patients with del(4)(p16), considering the poor survival and performance of the patients and that the investigation would be of no benefit for them.

The strongest association with ACC has been identified for $\operatorname{del}(1)(\mathrm{q} 42-\mathrm{q} 44)(P<0.0001)$. The relevance of this region for harboring an ACC gene search is well known (Gentile et al. 2003; Murayama et al. 1991). The possible involvement of the same gene(s) for NTD and ACC may be embryologically plausible. The fact that the fiber commissures connecting the right and the left cerebral hemispheres form from thickening at the cranial end of the telencephalon, which represents the zone of final neuropore closure (Larsen 2001), could support the assumption that these two processes are under control of genes which regulate the development of this particular region. Hemizygosity of the DISPA gene might be responsible for CNS malformation in case of $1 \mathrm{q} 42$ deletion. Mice embryos lacking $m D i s p A$ function display the cephalic defects which are reminiscent of HPE and also neural tube patterning defects (Ma et al. 2002). This corresponds to our results showing the association of the DISPA region to both malformations in humans, assuming that ACC could be a part of the HPE spectrum (Cohen 2001). The smallest region of overlap $(1,7 \mathrm{Mb})$ including the DISPA gene was newly identified in 7 patients with 1q41-1q42 deletions, although none of the reported patients had any brain abnormality (Shaffer et al. 2007). A 3,5-Mb critical region for microcephaly and ACC in 1q44 extending from RP11-80B9 to RP11-241M7 has recently been defined (Boland et al. 2007), and two candidates genes have been proposed. Taking into account a variety of brain malformations in 1q42-1q44 deletions, several genes in this region might be involved in brain development.

3 q13.3 has not been previously specifically discussed as a candidate locus of ACC causative genes in any review article. IGSF11 (immunoglobulin superfamily, member 11) is the strongest candidate gene for ACC in $3 q 13.3$ as it is expressed in the commissure fibers of the corpus callosum (Suzu et al. 2002). CDGAP gene (Cdc42 GTPase- activating protein) is also expressed in the corpus callosum and the fetal brain (Nagase et al. 1999). The important role of the genes located on 3q13.3 was currently supported by Lawson-Yuen et al. (2006). They reported a patient carrying a 3q13.3 deletion with complete agenesis of corpus callosum and provide a review of the literature with one further case of 3q13.3 deletions and ACC (Lawson-Yuen et al. 2006).

This approach to identify malformation loci has limitations. First, the quality and completeness of the cytogenetic and clinical descriptions in original publications is not uniform which concerns also recent array-CGH studies. Second, the statistical analysis assumes that each chromosome band can be treated equally. However, breakpoints involved in rearrangements are not randomly distributed and the role of predisposing low-copy repeats contributing to this disparity has been widely discussed (Shaw and Lupski 2004). This "clustering" phenomenon may reduce the resolution of chromosomal maps rather than cause an identification of false loci (Brewer et al. 1999). Third, if a disease causing gene locus is close to or even overlaps with a haplolethal region, it will not be detected with the strategy chosen. Fourth, the completeness of ascertainment of uncomplicated aberrations in the database is not known. Furthermore, the design of this study did not include cases with double imbalance and therefore defects occurring due to interaction of several genes (or one gene and one or several controlling elements) could not be detected. Finally, it has to be emphasized that this method would not be expected to reliably identify the locations of recessive genes and would not identify disease genes acting via other mechanisms of genetic dominance (Brewer et al. 1998; Wilkie 1994). With an increasing number of submicroscopic deletions and duplications being identified it is expected that the utility of this approach will markedly improve.

In summary, this deletion/duplication map of human brain malformations has identified several new candidate loci and confirmed many others. We have suggested two new candidate genes for Agenesis of corpus callosum. The $1 \mathrm{q} 42$ locus has been shown to be highly significant for both Agenesis of corpus callosum and Neural tube defects. 
Acknowledgments The authors are grateful to Prof. Dr. Burkhardt Seifert for his help with statistical analysis and to Prof. David FitzPatrick for very helpful comments.

\section{References}

Aalfs CM, Fantes JA, Wenniger-Prick LJ, Sluijter S, Hennekam RC, van Heyningen V, Hoovers JM (1997) Tandem duplication of $11 \mathrm{p} 12-\mathrm{p} 13$ in a child with borderline development delay and eye abnormalities: dose effect of the PAX6 gene product? Am J Med Genet 73:267-271

Arvanitis D (1999) Congenital malformations of the nervous system. In: Panteliadis C, Darras B (eds) Encyclopaedia of peadiatric neurology, Thessaloniki

Avsian-Kretchmer O, Hsueh AJ (2004) Comparative genomic analysis of the eight-membered ring cystine knot-containing bone morphogenetic protein antagonists. Mol Endocrinol 18:1-12

Becker KG, Lee IJ, Nagle JW, Canning RD, Gado AM, Torres R, Polymeropoulos MH, Massa PT, Biddison WE, Drew PD (1997) C2H2-171: a novel human cDNA representing a developmentally regulated POZ domain/zinc finger protein preferentially expressed in brain. Int J Dev Neurosci 15:891-899

Bedeschi M, Bonaglia M, Grasso R, Pellegri A, Garghentino R, Battaglia M, Panarisi A, Rocco M, Balottin U, Bresolin N, Bassi M, Borgatti R (2006) Agenesis of corpus callosum: clinical and genetic study in 63 young patients. Pediatr Neurol 34:186-193

Boland E, Clayton-Smith J, Woo VG, McKee S, Manson FD, Medne L, Zackai E, Swanson EA, Fitzpatrick D, Millen KJ, Sherr EH, Dobyns WB, Black GC (2007) Mapping of deletion and translocation breakpoints in 1q44 implicates the serine/threonine kinase AKT3 in postnatal microcephaly and agenesis of the corpus callosum. Am J Hum Genet 81:292-303

Brewer C, Holloway S, Zawalnyski P, Schinzel A, FitzPatrick D (1998) A chromosomal deletion map of human malformations. Am J Hum Genet 63:1153-1159

Brewer C, Holloway S, Zawalnyski P, Schinzel A, FitzPatrick D (1999) A chromosomal duplication map of malformations: regions of suspected haplo- and triplolethality - and tolerance of segmental aneuploidy-in humans. Am J Hum Genet 64:1702-1708

Brown S, Gersen S, Anyane-Yeboa K, Warburton D (1993) Preliminary definition of a "critical region" of chromosome 13 in q32: report of 14 cases with $13 q$ deletions and review of the literature. Am J Med Genet 45:52-59

Calver AR, Michalovich D, Testa TT, Robbins MJ, Jaillard C, Hill J, Szekeres PG, Charles KJ, Jourdain S, Holbrook JD, Boyfield I, Patel N, Medhurst AD, Pangalos MN (2003) Molecular cloning and characterisation of a novel GABAB-related G-protein coupled receptor. Brain Res Mol Brain Res 110:305-317

Carey JC, Viskochil DH (2007) Status of the human malformation map: 2007. Am J Med Genet A 143:2868-2885

Cohen M (2004) SHH and Holoprosencephaly. In: Epstein C, Erickson $\mathrm{R}$, Wynshaw-Boris A (eds) Inborn errors of development the molecular basis of clinical disorders of morphogenesis. University press, Oxford, pp 240-248

Cohen MM Jr (2001) Problems in the definition of holoprosencephaly. Am J Med Genet 103:183-187

de Vries BB, Pfundt R, Leisink M, Koolen DA, Vissers LE, Janssen IM, Reijmersdal S, Nillesen WM, Huys EH, Leeuw N, Smeets D, Sistermans EA, Feuth T, van Ravenswaaij-Arts CM, van Kessel AG, Schoenmakers EF, Brunner HG, Veltman JA (2005) Diagnostic genome profiling in mental retardation. Am J Hum Genet 77:606-616

Dobyns WB (1996) Absence makes the search grow longer. Am J Hum Genet 58:7-16
Gentile M, Di Carlo A, Volpe P, Pansini A, Nanna P, Valenzano MC, Buonadonna AL (2003) FISH and cytogenetic characterization of a terminal chromosome 1q deletion: clinical case report and phenotypic implications. Am J Med Genet A 117:251-254

Grinberg I, Millen KJ (2005) The ZIC gene family in development and disease. Clin Genet 67:290-296

Grinberg I, Northrup H, Ardinger H, Prasad C, Dobyns WB, Millen KJ (2004) Heterozygous deletion of the linked genes ZIC1 and ZIC4 is involved in Dandy-Walker malformation. Nat Genet 36:10531055

Gunhaga L, Marklund M, Sjodal M, Hsieh JC, Jessell TM, Edlund T (2003) Specification of dorsal telencephalic character by sequential Wnt and FGF signaling. Nat Neurosci 6:701-707

Halford S, Freedman MS, Bellingham J, Inglis SL, Poopalasundaram S, Soni BG, Foster RG, Hunt DM (2001) Characterization of a novel human opsin gene with wide tissue expression and identification of embedded and flanking genes on chromosome 1q43. Genomics 72:203-208

Harada H, Suzu S, Hayashi Y, Okada S (2005) BT-IgSF, a novel immunoglobulin superfamily protein, functions as a cell adhesion molecule. J Cell Physiol 204:919-926

Joly G, Lapierre JM, Ozilou C, Gosset P, Aurias A, de Blois MC, Prieur M, Raoul O, Colleaux L, Munnich A, Romana S, Vekemans M, Turleau C (2001) Comparative genomic hybridisation in mentally retarded patients with dysmorphic features and a normal karyotype. Clin Genet 60:212-219

Kelly PC, Blake WW, Davis JR (1989) Tandem Y/6 translocation with partial deletion 6 (p23-pter). Clin Genet 36:204-207

Kirikoshi H, Katoh M (2002) Expression of WRCH1 in human cancer and down-regulation of WRCH1 by beta-estradiol in MCF-7 cells. Int J Oncol 20:777-783

Klein OD, Backstrand K, Cotter PD, Marco E, Sherr E, Slavotinek A (2005) Case report: Y;6 translocation with deletion of 6p. Clin Dysmorphol 14:93-96

Larsen W (2001) Human embryology, 3rd edn. Churchill Livingstone, New York

Lawson-Yuen A, Berend SA, Soul JS, Irons M (2006) Patient with novel interstitial deletion of chromosome 3 q13.1q13.3 and agenesis of the corpus callosum. Clin Dysmorphol 15:217-220

Leader B, Leder P (2000) Formin-2, a novel formin homology protein of the cappuccino subfamily, is highly expressed in the developing and adult central nervous system. Mech Dev 93:221-231

Ledbetter SA, Kuwano A, Dobyns WB, Ledbetter DH (1992) Microdeletions of chromosome $17 \mathrm{p} 13$ as a cause of isolated lissencephaly. Am J Hum Genet 50:182-189

Lin RJ, Cherry AM, Chen KC, Lyons M, Hoyme HE, Hudgins L (2005) Terminal deletion of $6 \mathrm{p}$ results in a recognizable phenotype. Am J Med Genet A 136:162-168

Lo Nigro C, Chong CS, Smith AC, Dobyns WB, Carrozzo R, Ledbetter DH (1997) Point mutations and an intragenic deletion in LIS1, the lissencephaly causative gene in isolated lissencephaly sequence and Miller-Dieker syndrome. Hum Mol Genet 6:157-164

Luo J, Balkin N, Stewart JF, Sarwark JF, Charrow J, Nye JS (2000) Neural tube defects and the $13 \mathrm{q}$ deletion syndrome: evidence for a critical region in 13q33-34. Am J Med Genet 91:227-230

Lurie IW (1993) Autosomal imbalance syndromes: genetic interactions and the origin of congenital malformations in aneuploidy syndromes. Am J Med Genet 47:410-416

Ma Y, Erkner A, Gong R, Yao S, Taipale J, Basler K, Beachy PA (2002) Hedgehog-mediated patterning of the mammalian embryo requires transporter-like function of dispatched. Cell 111:63-75

Menten B, Maas N, Thienpont B, Buysse K, Vandesompele J, Melotte C, de Ravel T, Van Vooren S, Balikova I, Backx L, Janssens S, De Paepe A, De Moor B, Moreau Y, Marynen P, Fryns JP, Mortier G, Devriendt K, Speleman F, Vermeesch JR (2006) Emerging patterns of cryptic chromosomal imbalance in patients with idio- 
pathic mental retardation and multiple congenital anomalies: a new series of 140 patients and review of published reports. J Med Genet 43:625-633

Mirza G, Williams RR, Mohammed S, Clark R, Newbury-Ecob R, Baldinger S, Flinter F, Ragoussis J (2004) Refined genotypephenotype correlations in cases of chromosome $6 \mathrm{p}$ deletion syndromes. Eur J Hum Genet 12:718-728

Morris JA, Kandpal G, Ma L, Austin CP (2003) DISC1 (Disrupted-InSchizophrenia 1) is a centrosome-associated protein that interacts with MAP1A, MIPT3, ATF4/5 and NUDEL: regulation and loss of interaction with mutation. Hum Mol Genet 12:1591-1608

Murayama K, Greenwood RS, Rao KW, Aylsworth AS (1991) Neurological aspects of del(1q) syndrome. Am J Med Genet 40:488492

Nagase T, Ishikawa K, Suyama M, Kikuno R, Hirosawa M, Miyajima N, Tanaka A, Kotani H, Nomura N, Ohara O (1999) Prediction of the coding sequences of unidentified human genes. XIII. The complete sequences of 100 new cDNA clones from brain which code for large proteins in vitro. DNA Res 6:63-70

Ozeki Y, Tomoda T, Kleiderlein J, Kamiya A, Bord L, Fujii K, Okawa M, Yamada N, Hatten ME, Snyder SH, Ross CA, Sawa A (2003) Disrupted-in-Schizophrenia-1 (DISC-1): mutant truncation prevents binding to NudE-like (NUDEL) and inhibits neurite outgrowth. Proc Natl Acad Sci USA 100:289-294

Panteliadis C, Pantzaris M (1999) Neural tube defects. In: Panteliadis C, Darras B (eds) Encyclopaedia of peadiatric neurology, Thessaloniki

Patel S, Barkovich AJ (2002) Analysis and classification of cerebellar malformations. AJNR Am J Neuroradiol 23:1074-1087

Pimenta AF, Fischer I, Levitt P (1996) cDNA cloning and structural analysis of the human limbic-system-associated membrane protein (LAMP). Gene 170:189-195

Pirola B, Bortotto L, Giglio S, Piovan E, Janes A, Guerrini R, Zuffardi O (1998) Agenesis of the corpus callosum with Probst bundles owing to haploinsufficiency for a gene in an $8 \mathrm{cM}$ region of $6 \mathrm{q} 25$. J Med Genet 35:1031-1033

Poss AF, Goldenberg PC, Rehder CW, Kearney HM, Melvin EC, Koeberl DD, McDonald MT (2006) Clinical experience with array CGH: Case presentations from nine months of practice. Am J Med Genet A 140:2050-2056

Ray K, Kunsch C, Bonner LM, Robishaw JD (1995) Isolation of cDNA clones encoding eight different human $\mathrm{G}$ protein gamma subunits, including three novel forms designated the gamma 4 , gamma 10, and gamma 11 subunits. J Biol Chem 270:2176521771

Rosenberg C, Knijnenburg J, Bakker E, Vianna-Morgante AM, Sloos W, Otto PA, Kriek M, Hansson K, Krepischi-Santos AC, Fiegler H, Carter NP, Bijlsma EK, van Haeringen A, Szuhai K, Tanke HJ (2006) Array-CGH detection of micro rearrangements in mentally retarded individuals: clinical significance of imbalances present both in affected children and normal parents. J Med Genet 43:180-186

Sarnat HB (2005) CNS malformations: gene locations of known human mutations. Eur J Paediatr Neurol 9:427-431

Schedl A, Ross A, Lee M, Engelkamp D, Rashbass P, van Heyningen V, Hastie ND (1996) Influence of PAX6 gene dosage on development: overexpression causes severe eye abnormalities. Cell $86: 71-82$

Schinzel A (2001) Catalogue of unbalanced chromosomal aberrations in man, 2nd edn. de Gruyter, Berlin

Schoumans J, Ruivenkamp C, Holmberg E, Kyllerman M, Anderlid BM, Nordenskjold M (2005) Detection of chromosomal imbal- ances in children with idiopathic mental retardation by array based comparative genomic hybridisation (array-CGH). J Med Genet 42:699-705

Shaffer L, Tommerup N (2005) ISCN 2005: international system for human cytogenetic nomenclature: recommendations of the international standing committee on human cytogenetics nomenclature. Karger, Basel

Shaffer LG, Theisen A, Bejjani BA, Ballif BC, Aylsworth AS, Lim C, McDonald M, Ellison JW, Kostiner D, Saitta S, Shaikh T (2007) The discovery of microdeletion syndromes in the post-genomic era: review of the methodology and characterization of a new 1q41q42 microdeletion syndrome. Genet Med 9:607-616

Shaw-Smith C, Redon R, Rickman L, Rio M, Willatt L, Fiegler H, Firth H, Sanlaville D, Winter R, Colleaux L, Bobrow M, Carter NP (2004) Microarray based comparative genomic hybridisation (array-CGH) detects submicroscopic chromosomal deletions and duplications in patients with learning disability/mental retardation and dysmorphic features. J Med Genet 41:241-248

Shaw CJ, Lupski JR (2004) Implications of human genome architecture for rearrangement-based disorders: the genomic basis of disease. Hum Mol Genet 13(Spec no 1):R57-R64

Strausberg RL, Feingold EA, Grouse LH, Derge JG, Klausner RD, Collins FS, Wagner L, Shenmen CM, Schuler GD, Altschul SF, Zeeberg B, Buetow KH, Schaefer CF, Bhat NK, Hopkins RF, Jordan H, Moore T, Max SI, Wang J, Hsieh F, Diatchenko L, Marusina K, Farmer AA, Rubin GM, Hong L, Stapleton M, Soares MB, Bonaldo MF, Casavant TL, Scheetz TE, Brownstein MJ, Usdin TB, Toshiyuki S, Carninci P, Prange C, Raha SS, Loquellano NA, Peters GJ, Abramson RD, Mullahy SJ, Bosak SA, McEwan PJ, McKernan KJ, Malek JA, Gunaratne PH, Richards S, Worley KC, Hale S, Garcia AM, Gay LJ, Hulyk SW, Villalon DK, Muzny DM, Sodergren EJ, Lu X, Gibbs RA, Fahey J, Helton E, Ketteman M, Madan A, Rodrigues S, Sanchez A, Whiting M, Young AC, Shevchenko Y, Bouffard GG, Blakesley RW, Touchman JW, Green ED, Dickson MC, Rodriguez AC, Grimwood J, Schmutz J, Myers RM, Butterfield YS, Krzywinski MI, Skalska U, Smailus DE, Schnerch A, Schein JE, Jones SJ, Marra MA (2002) Generation and initial analysis of more than 15, 000 full-length human and mouse cDNA sequences. Proc Natl Acad Sci USA 99:1689916903

Strittmatter SM, Fankhauser C, Huang PL, Mashimo H, Fishman MC (1995) Neuronal pathfinding is abnormal in mice lacking the neuronal growth cone protein GAP-43. Cell 80:445-452

Sudha T, Dawson AJ, Prasad AN, Konkin D, de Groot GW, Prasad C (2001) De novo interstitial long arm deletion of chromosome 3 with facial dysmorphism, Dandy-Walker variant malformation and hydrocephalus. Clin Dysmorphol 10:193-196

Suzu S, Hayashi Y, Harumi T, Nomaguchi K, Yamada M, Hayasawa H, Motoyoshi K (2002) Molecular cloning of a novel immunoglobulin superfamily gene preferentially expressed by brain and testis. Biochem Biophys Res Commun 296:1215-1221

Tyson C, Harvard C, Locker R, Friedman JM, Langlois S, Lewis ME, Van Allen M, Somerville M, Arbour L, Clarke L, McGilivray B, Yong SL, Siegel-Bartel J, Rajcan-Separovic E (2005) Submicroscopic deletions and duplications in individuals with intellectual disability detected by array-CGH. Am J Med Genet A 139:173185

Wilkie AO (1994) The molecular basis of genetic dominance. J Med Genet 31:89-98

Willner J, Vosatka R, Hirschhorn K (1990) Interstitial deletion of chromosome $3 q$ with Dandy-Walker syndrome. Am J Hum Genet 47:A44 